\title{
China's Expansion of Influence in Africa: projection, perception and prospects in Southern African countries
}

\author{
Xiaoling Zhang, Herman Wasserman, Winston Mano
}

\section{Brief bio}

Dr Xiaoling Zhang is Associate Professor and Head, School of Contemporary Chinese Studies, UK's University of Nottingham China Campus in Ningbo. Her research interests span the transformation of media, culture and society in China. She has published widely on the shifting cultural and media landscapes in China, exploring the social, cultural and political implications of China's transition to a more information-rich and communication-intensive society. Supported by the UK BA and AHRC and the Taiwan CCKF, Dr Zhang also explores how China promotes its "soft" power through the expansion of its media and communication channels around the world, and assesses its actual penetration and possible impact on the changing global information flow.

Herman Wasserman, Professor and Director, Centre for Film and Media Studies, University of Cape Town, South Africa, has published widely on media in post-apartheid South Africa. He edits the academic journal Ecquid Novi: African Journalism Studies published by Taylor and Francis, and sits on the editorial boards of nine other international journals. He heads the International Communication Section of the International Association for Media and Communication Research, and is an elected member of the Academy of Science of South Africa and of the South African National Editors' Forum. He has participated in several research collaborations funded by amongst others the UK BA and ESRC, the Andrew W. Mellon Foundation, the Academy of Finland, and the Chiang-Ching Kuo Foundation for International Scholarly Exchange in Taiwan.

Dr Winston Mano is Associate Professor, Director, African Media Centre, the University of Westminster, UK. Mano joined the University of Westminster's Communication and Media Research Institute (CAMRI) from the University of Zimbabwe in 2000 on a PhD Teaching Studentship and obtained his doctorate degree in 2004. He has since published widely on African radio, music, media audiences, new media and democracy, ChinaAfrican media relations, African democracy and development. He is the Principal Editor of the Journal of African Media Studies published by Intellect Ltd. Mano has helped establish the CAMRI Africa Media Series of Conferences since 2005. He has participated in research collaborations funded by amongst others the British Academy, and the Chiang-Ching Kuo Foundation for International Scholarly Exchange in Taiwan. 


\title{
China's Expansion of Influence in Africa: projection, perception and prospects in Southern African countries ${ }^{1}$
}

\begin{abstract}
China's multi-faceted endeavor to expand its influence in Africa has attracted worldwide scholarly and media attention. This paper examines the different moments of China's soft power endeavor from projection through its state media to representation and livedexperiences in South Africa and Zimbabwe, two African countries which receive a high level of attention in China's policymaking. Through such inter-disciplinary methodologies as content analysis, on-line questionnaire and in-depth interviews in China, South Africa and Zimbabwe, the authors find that China's state-engineered soft power initiatives have resulted in partial success in the two countries. It indicates that China faces many challenges in fully accomplishing its intended goal. The paper throws light on China's political impact in Africa as China reshapes the continent economically.
\end{abstract}

\section{Key words}

Sino-Africa relations; partial success; projection; prospects; reception; soft power

China's presence in Africa dwarfs many other powers. ${ }^{2}$ Observers have often cited the rising trade and investment figures to show 'the extent, the intensity, the speed, and the impact of China's relations in Africa' ${ }^{3}$-- China is now Africa's largest trading partner, with the bilateral trade volume surging from \$10 billion in 2000 to $\$ 200$ billion in 2012 . Indeed with limited investment in Africa before the 2000s, China's cumulative investment in Africa reached \$21 billion in 2012, with over 2,000 Chinese companies operating across the continent. ${ }^{4}$ Africa has thus become China's 'second largest overseas labor and project contracting market and fourth largest destination for outward investment'. The scale of China's presence in Africa is made visible by the increasing number of bridges, dams, roads, railroads, stadiums, ports, oil infrastructure, and radio and TV stations by its state-run firms. Ian Taylor calls this rise of China's presence in

\footnotetext{
${ }^{1}$ Acknowledgement

2 David Shambaugh, 'Coping with a conflicted China', The Washington Quarterly 34(1), (Winter 2011), p. 22.

${ }^{3}$ David H. Shinn and Joshua Eisenman, China and Africa: A Century of Engagement (Philadelphia: University of Pennsylvania Press, 2012), p. ix.

${ }^{4}$ Xiangming Chen and Garth Myers, 'China and Africa: the crucial urban connection', The European Financial Review, (28 December 2013), available at: http://www.europeanfinancialreview.com/?p=557.

${ }^{5}$ Wenping He, 'More soft power needed in Africa', Forum on China-Africa Cooperation, (28 February

2012), available at: http://www.focac.org/eng/xsj1/xzzs/t909111.htm (accessed 18 May 2014).
} 
Africa 'arguably the most important development for the continent since the end of the Cold War'. ${ }^{6}$ Chinese President Xi Jinping's first high profile overseas trip to Africa in March 2013 confirmed China's continuing engagement by committing further financial assistance. $^{7}$

China's engagement in Africa is not just economic. What has also attracted scholarly and media attention worldwide is China's great endeavor to gain influence in Africa, just as Xinhua Executive Deputy Editor-in-Chief Zhou Qisheng said: 'we cannot just rely on economic power alone!' ${ }^{8}$ In addition to such efforts as setting up Confucius Institutes and providing cultural exchange programs, China has greatly increased the momentum of establishing its media presence in Africa as important instruments of soft power, ${ }^{9}$ causing some to believe that China has already displaced European, American and Japanese diplomatic and capitalistic soft power in many sub-Saharan African countries, ${ }^{10}$ and others to claim that 'China aims to dominate the African media sector with the introduction of a radio broadcaster, news agency, TV station and newspaper to the African market'. ${ }^{11}$

Indeed, Xinhua News Agency, Central China Television (CCTV), China Radio International (CRI) and China Daily -- the "Big Four" official media outlets as China's former Minister of Foreign Affairs Yang Jiechi called them ${ }^{12}$-- have all increased their presence and expanded their reach as important instruments of soft power in Africa. Xinhua, the world's largest news agency with 13 bureaus in English, nine in French and two in Portuguese in Africa, has developed the most outlets of any Chinese or western news agency on the continent. In 2006, its Africa Regional Bureau in Nairobi took over the production and distribution of French language reports from the Paris Bureau. Two years later, Xinhua launched its China African News Service. CNC World, the English-

\footnotetext{
${ }^{6}$ Ian Taylor, 'China's challenges: Africa', The Diplomat (15 February 2013), available at: http://www.thediplomat.com/whats-next-china/africa/.

7 'China set to expand influence in Africa on back of Xi Jinping's trip', The Economic Times (31 March 2013), available at: http://www.articles.economictimes.indiatimes.com/2013-03-

31/news/38163340_1_african-leaders-south-africa-brics (accessed 2 March 2014).

${ }^{8}$ Quoted in David Shambaugh, China Goes Global: The Partial Power (New York: Oxford University Press, 2013), p.230.

${ }^{9}$ For soft power see Joseph Nye, Soft Power: the Means to Success in World Politics (New York: PublicAffairs, 2004); Joseph Nye, 'Think again: soft power', Foreign Policy 1, (23 February 2006), available at: http://www.foreignpolicy.com/articles/2006/02/22/think_again_soft_power (accessed 2 October 2014); Joseph Nye, Future of Power (New York: Public Affairs, 2012); for China's embrace of soft power see Hongying Wang and Yeh-Chung Lu, 'The conception of soft power and its policy implications: a comparative study of China and Taiwan', Journal of Contemporary China 17(56), (August 2008), pp.425-447; for China's international communications as instruments of soft power see Xiaoling Zhang'China's international broadcasting: the case of CCTV international', in J. Wang, ed, Soft Power in China: Public Diplomacy through Communication (Palgrave Macmillan, 2010), pp.57 - 71.

${ }^{10}$ Chuka Enuka, 'The forum on China-Africa cooperation (FOCAC): a framework for China's reengagement with Africa in the 21st century', Pakistan Journal of Social Sciences 30(2),(2010), pp. $209-218$.

${ }^{11}$ Nadina Schwarzbeck, 'China expands media reach in Africa', Deutsche Welle, (07 January 2013), available at: http://www.dw.de/china-expands-media-reach-in-africa/a-16503491 (accessed 26 October 2014).

12 Jiechi Yang, 'A changing China in a changing world', (paper presented at the Munich Security Conference, Germany, 5 February, 2010), available at: http://www.maximsnews.com/news20100212ChinaYangJiechiMunich11002120101.htm (accessed 18 February 2012).
} 
language TV channel of Xinhua, reached cable television audiences in Africa in $2011 .^{13}$ Its launch of mobile news in sub-Saharan Africa in April 2011 also enabled about 17 million Kenyan mobile subscribers to receive Xinhua's latest news. ${ }^{14}$ China has also stepped up its penetration of African airwaves. On 26 February 2006, CRI launched its first overseas station with its FM channels in three East African cities and its AM channel covering all of Kenya. China's leading English-language state newspaper, China Daily, launched its Africa Weekly edition in late 2012. It is published in Nairobi and distributed on Kenya Airways flights and other venues. What York considers 'the centerpiece of China's media empire', ${ }^{15}$ the new CCTV hub in Nairobi and its flagship show, Africa Live, were launched in January 2012. Every day CCTV Africa provides an hour-long program for the global CCTV News. CCTV's mobile TV application I Love Africa was also launched in January 2012.

To ensure readership and audience, these media organizations purchase space in African newspapers and increase the amount of news-sharing. Shinn and Eisenman reported that Xinhua has bought space in eight Zimbabwe state-controlled community newspapers which run international pages carrying Xinhua stories and pictures; it also publishes collaborative stories with South Africa's official Bua News Agency. ${ }^{16}$ Likewise, CCTV enters local networks by exchanging news programs with local media organizations. For instance, while CCTV is already available to many Zimbabweans who have free-to-air satellite receivers, in November 2011 China sealed a deal with the Ministry of Information for the state-run Zimbabwe Broadcasting Cooperation (ZBC) and CCTV to share news programming. Africa Live is also broadcast on primetime slots in Kenyan stations. In 2010, Togolese authorities and CRI and CCTV officials agreed that Radio Lome and Togolese Television would broadcast China's French-language reports while receiving technical and material assistance for modernizing their radio and TV stations. ${ }^{17}$

In addition to the expansion of the 'Big Four' media outlets, China also provides infrastructural and technical support to the media sector in Africa. According to Shinn and Eisenman, countries including Comoro Islands, the DRC, the Congo, Equatorial Guinea, Lesotho, Malawi, Mali, Togo, Zambia, and Zimbabwe have all received radio equipment from China; the donation of computer systems to Zimbabwe's state-run Herald newspaper is another case in point. Other technical support includes transmitters, towers, generators and antennae. ${ }^{18}$

The training sessions and workshops for African journalists and editors under the framework of the Forum on China-Africa Cooperation (FOCAC) are another source of attention in Sino-Africa relations. Between 2004 and 2011 China held eight training

\footnotetext{
${ }^{13} \mathrm{Yu}$-shan $\mathrm{Wu}$, 'The rise of China's state-led media dynasty in Africa', South African Institute of International Affairs Occasional Paper (117), (June 2012).

14 'Xinhua Mobile Newspaper delivers soft-launch in Kenya', Xinhuanet, last modified19 April, 2011, http://news.xinhuanet.com/english2010/china/2011-04/19/c_13836429.htm, (accessed 18 June 2012).

${ }^{15}$ Geoffrey York, 'Why China is making a big play to control Africa's media', The Globe and Mail (Nairobi), (11 September 2013), available at: http://www.theglobeandmail.com/news/world/media-agendachina-buys-newsrooms-influence-in-africa/article14269323/ (accessed 2 November 2014).

${ }^{16}$ Shinn and Eisenman, China and Africa: A Century of Engagement, p. 205.

${ }^{17}$ Shinn and Eisenman, China and Africa: A Century of Engagement, p. 210.

${ }^{18}$ Fackson Banda, 'China in the African Mediascape: doing better journalism', Rhodes Journalism Review (29), (September 2009), pp. $52-53$.
} 
workshops for African media, sponsoring training for about 300 African media officials from 48 African countries in China. ${ }^{19}$ According to Zimbabwe's Herald, in the year of 2011 alone, 400 Zimbabwean government officers attended seminars in China, and 30 journalists went to China for training. ${ }^{20}$

China's recent direct investment in South African media is considered a new phase in the expansion of China's media across Africa. In August 2013, StarTimes, the fastestgrowing and most influential Digital TV operator in the region with registered branches in 23 countries and operation in 12 countries, purchased a 20 per cent stake in South African satellite television provider TopTV (renamed StarSat). StarTimes is granted the status of "Key Cultural Export Enterprise" and the only certified private enterprise in China to contract foreign projects in the radio \& television industry. The inspection from high level party officials to StarTimes subsidiaries in Africa including Li Changchun, Liu Yunshan and Li Yuanchao, underscores the importance the CCP accorded the company. CCTV, backed up by the China-Africa Development Fund, is believed to be behind the Chinese consortium that provided 20 per cent of the financing for the Sekunjalo group, with links to the ruling African National Congress, to purchase Independent News and Media. ${ }^{21}$ The Independent Group, one of the most powerful media groups in the country, owns daily newspapers in all of the major cities.

However, just as controversial as China's increasing economic engagement with Africa has been, ${ }^{22}$ concerns over China's media development are many. Reporters without Borders, for instance, contends that China's involvement in Africa is 'toxic for democracy'. ${ }^{23}$ Critical questions are being asked about what Chinese investment in media may mean for editorial independence and democratic media culture in South Africa. For example, Prof. Anton Harber from the University of the Witwatersrand, South Africa, asked: 'Is this just investment, or is it colonialism with Chinese characteristics? How will their media investments serve their interests and will this affect our media culture? ${ }^{24}$

A small but growing number of scholars are starting to examine the impact of China's increased involvement in Africa as it pertains to the media. ${ }^{25}$ However, few studies have

\footnotetext{
${ }^{19}$ Shinn and Eisenman, China and Africa: A Century of Engagement, p. 209.

${ }^{20}$ Herald Reporter, '30 Journalists leave for China', The Herald (Zimbabwe), (28 November 2011), available at: http://www.herald.co.zw/index.php?option=com_content $\& v i e w=a r t i c l e \& i d=27772: 30$ journalists-leave-for-china\&catid=38:local-news\&Itemid=131 (accessed 16 November 2012).

${ }^{21}$ Anton Harber, 'Chinese "soft diplomacy" enters South Africa's media space', Business Day Live (27 June 2013), available at: http://www.bdlive.co.za/opinion/columnists/2013/06/27/chinese-soft-diplomacy-enterssouth-africas-media-space (accessed 12 June 2014).

22 See, e.g, Deborah Brautigam, The Dragon's Gift: The Real Story of China in Africa' (Oxford: Oxford University Press, 2009); Shinn and Eisenman, China and Africa: A Century of Engagement; Sanusha Naidu and Kweku Ampiah, Crouching Tiger, Hidden Dragon?: Africa and China (Scottsville: University of KwaZulu-Natal Press.2008);Howard W. French, China's Second Continent: How a Million Migrants Are Building a New Empire in Africa (New York: Alfred A. Knopf, 2014).

23 'China 'toxic for Africa freedom', BBC News, last modified 13 February 2008, available at: http: //www.news.bbc.co.uk/2/hi/africa/7242832.stm (accessed 12 October 2013).

${ }^{24}$ Anton Harber, 'Chinese "soft diplomacy" enters South Africa's media space'.

${ }^{25}$ See, e.g., Xin Xin, 'Xinhua News Agency in Africa', Journal of African Media Studies 1(3), (1 December 2009), pp. 363-377; Fackson Banda, 'China in the African Mediascape: doing better journalism'; Shinn and Eisenman, China and Africa: A Century of Engagement; Xiaoling Zhang, 'How ready is China for a China-style world order? China's state media discourse under construction', Ecquid Novi: African Journalism Studies 34(3), (2013), pp.79-101; Iginio Gaglardione, 'China as a persuader: CCTV Africa's first steps in the African mediasphere', Ecquid Novi: African Journalism Studies 34(3), (2013), pp. 15 - 34;
} 
looked at the whole process of soft power involving not only China's projection but also the reception in Africa. Firstly, due to the difficulties of getting to interview Chinese officials, there is a lack of empirical data on China's official justifications for its engagement in Africa. Secondly, as Max has rightly observed, 'the media plays a big part in influencing Africa's perception of China', ${ }^{26}$ examinations of African media representations of China can shed light on how African media public view China. However, such examinations are only starting to emerge, and an insight into African editors' and journalists' views on China's influence is missing. Although recent opinion polls by Pew Research Centre and BBC World Service tell us that China is receiving mostly positive views in Arica, ${ }^{27}$ their coverage of African countries is limited and does not tell us the broader socio-political, economic and cultural context.

This paper draws on public diplomacy grounded in the notion of Joseph Nye's soft power, ${ }^{28}$ or, in Melissen's words, one of soft power's key instruments. ${ }^{29}$ This analytical lens allows the authors to examine the different moments of soft power - projection, representation, and lived-experiences. Two interrelated investigations are conducted in answering the following questions, thereby contributing to the construction of theoretical frameworks in understanding Chinese influence in Africa and offering insights into the effectiveness of China's assertion in two southern African countries:

- How does China wish to guide international views of Sino-Africa relations?

- What are the perspectives of Chinese officials, media professionals and academics on Sino-Africa relations in general and media relations in particular?

- How is China reported on major media reports in South Africa and Zimbabwe?

- What are the editors and journalists' views on China's influence?

First, analysis is conducted of the languages and images as projected by China Daily, Xinhuanet and CCTV Africa, three major official outlets for the promotion of China's influence, followed by extensive interviews ${ }^{30}$ with Chinese officials, media professionals and academics in Beijing and Nairobi. These serve not only as important foundations in assessing how China through its discursive official media outlets wishes to guide international views of Sino-Africa relations, but also to give voice to the perspectives of Chinese officials, media professionals and academics on the relations.

Secondly, analysis is undertaken of major media reports on China in South Africa and Zimbabwe, contextualized by an online questionnaire for journalists and editors in South Africa and in-depth interviews with journalists, officials at the Journalists Unions and

Shubo Li and Helge Ronning, 'Half-orchestrated, half freestyle: Soft power and reporting Africa in China', Ecquid Novi: African Journalism Studies 34(3), (2013), pp. 93 - 141.

${ }^{26}$ Rebol Max, Pragmatism and Non- Interference: Explaining China's Soft Power in Africa. Ph.D. dissertation, Fudan University, 2011.

27 'Global Opposition to U.S. Surveillance and Drones, But Limited Harm to America's Image', last modified 12 July, 2014, available at: http://www.pewglobal.org/2014/07/14/chapter-1-the-americanbrand/(accessed 08 April 2013).

${ }^{28}$ Shawn Powers and Eytan Gilboa, 'The public diplomacy of al jazeera', in New Media and the New Middle East, ed. Philip Seib (New York: Palgrave Macmillan, 2007), pp. 53 - 80.

${ }^{29}$ Jen Melissen, 'The new public diplomacy: Between theory and practice', p.4, in The New Public Diplomacy: Soft Power in International Relations, ed. Jen Melissen (New York: Palgrave Macmillan, 2005), pp.3-23.

${ }^{30}$ All respondents and interviewees were granted confidentiality following the ethics regulations of the authors' institutions. 
politicians in Zimbabwe. The authors are fully aware that the media in Africa are far from homogenous entities. So instead of identifying a consistent response to China's presence in Africa, the authors follow Yun Sun who identifies two types of African countries which receive a higher level of attention in China's policymaking: South Africa, a regional political and economic leader, and Zimbabwe which belongs to the category of 'problematic countries' not only because China has large vested economic interests in the natural resources, but also because its volatile internal politics often raise international concerns and spark criticism that China is 'propping up' the authoritarian regime through economic deals and international political support. ${ }^{31}$ The questionnaire and the interviews serve to establish editors and journalists' views on China, which are very likely to play out in their practice.

\section{China's story}

The work on China's perspective covers the period from 2011, when the project started, to May 2014. An examination and analysis of China Daily and the online news service of Xinhua News Agency, Xinhuanet, was first conducted in March and April 2011 respectively. ${ }^{32}$

As expected, in addition to framing and legitimizing China's involvement with Africa, African countries receive more positive coverage on the websites of China Daily and Xinhua, as is shown below.

\footnotetext{
${ }^{31}$ Yun Sun, 'Africa in China's foreign policy', Brookings, (April 2014), p.20, available at: http://www.brookings.edu/research/papers/2014/04/10-africa-china-foreign-policy-sun (accessed 8 August 2014).

32 The examination and analysis of China Daily was conducted of the first 10 pages that came up with the search word "Africa." A similar analysis of online news service of Xinhua News Agency, Xinhuanet, was conducted.
} 

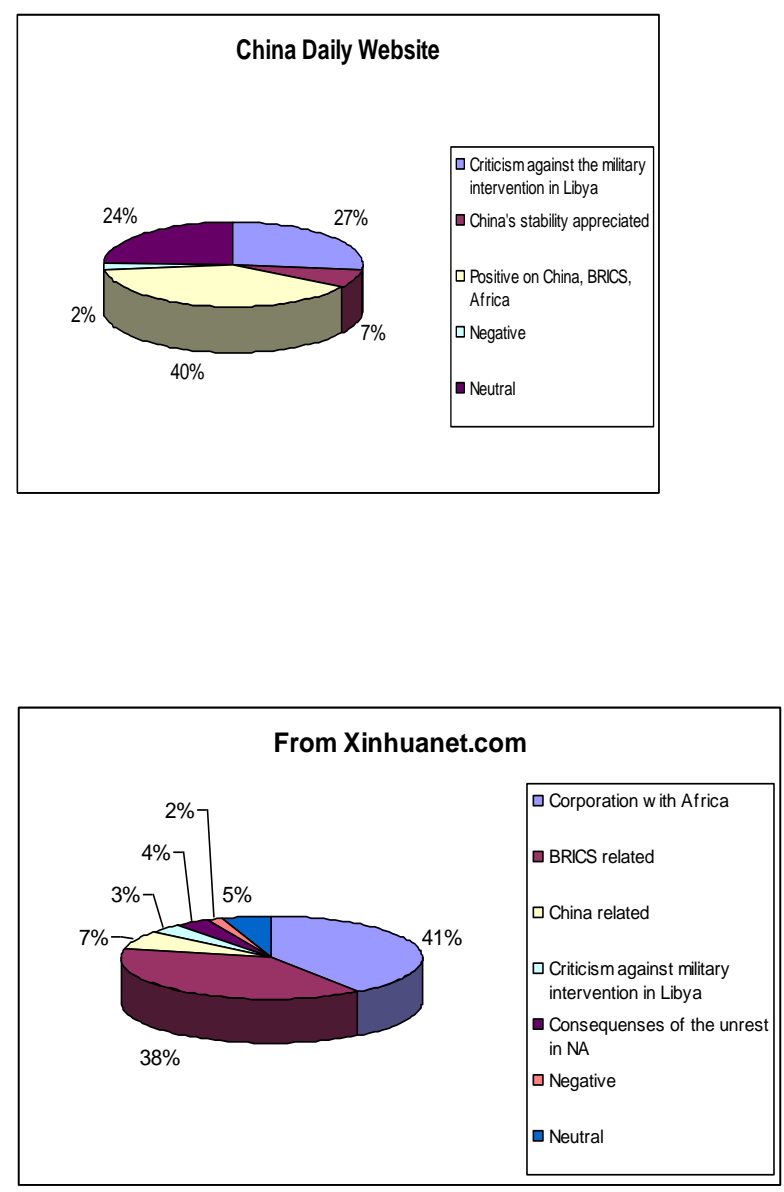

Figure 1. Tone of reports on Africa by China Daily website: 2011

Figure 2. Tone of reports on Africa by Xinhuanet.com: 2011

Examinations of the two official websites also reveal that negative issues tend to be reported positively. When talking about its involvement in Africa, China used a mixture of defensive and offensive rhetoric. In response to the skepticism of China's presence in Africa, China employs a number of tactics to shift its image from the 'uncertain other' to the 'friendly other'. The relationship between China and Africa was overwhelmingly portrayed as a mutually beneficial one and based on principles of equal partnership rather than a neo-colonialist attitude. Also in line with expectations, the reports tend to have no in-depth analysis.

Most noticeable from the examination is the emerging discourse from China calling on Africa to change the established world order which was argued to be established without the participation of the emerging economies. This is especially evident on Xinhuanet, which highlights consensus, common standing and mutual prosperity of China and Africa. This discourse highlights the newer, emerging rhetoric of global partnership based on equality. These two websites also continue to identify China as a developing country, aligning with African countries to challenge the West-dominated global order. 
Almost one year later, ${ }^{33}$ data collected from African News and the current affairs program Talk Africa on CCTV Africa reveal seven significant recurring themes which are similar to the findings from China Daily and Xinhuanet in 2011, but with one highly noticeable difference, namely the absence of a clear tendency towards positive news on Africa. The main themes are: ${ }^{34}$

1. Condemnation of western intervention in African affairs;

2. Democracy, revolution, elections, crisis linked with instability;

3. Reforming international systems;

4. Chinese support without conditions and China's role in Africa;

5. China's positive construction of the African image;

6. Questioning USA's behavior in Africa;

7. Solidarity and camaraderie with Africa on the international stage.

As the figure below shows, on many days negative reporting outweighs positive reporting. This practice indicates the efforts of Chinese media in general but CCTV in particular to make the programme more attractive to both the African and international audiences.

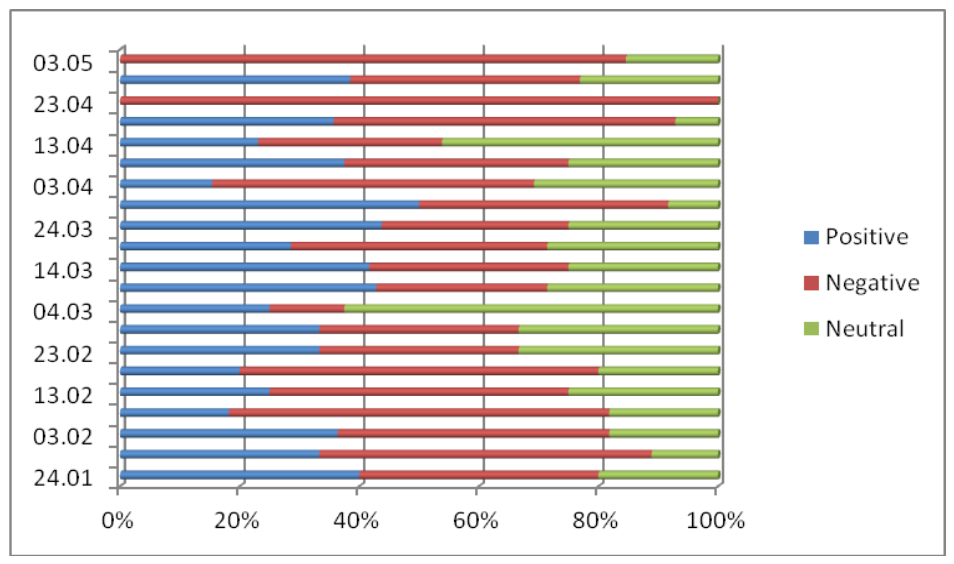

Figure 3. Tone of reports on Africa by CCTV Africa: 24.01.2012 - 03.05.2012

Interviews conducted in Beijing and Nairobi in 2011, 2012 and 2014 include six officials from the Ministry of Foreign Affairs, the State Council Information Office and the media industry (CRI, CCTV News, CCTV Africa, Global Times), 18 media workers from CCTV News including four local and two Chinese employees of CCTV Africa, Xinhua News Agency, China Daily and Global Times, and six media academics from Tsinghua University, China University of Communications and Renmin University in Beijing.

Interviews with officials provide a rare glimpse into some Chinese officials' mind-sets on Sino-Africa relations. For instance, while he agreed that China needs resources from Africa, one high-level official argued, 'China is not a threat to the West as it recovers

\footnotetext{
${ }^{33}$ Data from African News: every fifth day from its first programme on 24 January 2012 to 30 April 2012, so that the data covers three Mondays, Tuesdays, Wednesdays, Thursdays, Fridays, Saturdays, and Sundays respectively; from Talk Africa: 15 weeks of the weekly programme in the same period.

${ }^{34}$ For a fuller discussion on the themes see Zhang, 'How ready is China for a China-style world order? China's state media discourse under construction'.
} 
petroleum in the least hospitable area' ${ }^{35}$ Besides, he added, it was a mutually beneficial exchange. Interviews also showed that China was keen to construct a discourse that was different from the West. One official from the State Council Information Office reasoned that for a developing country such as China, it was more important to feed everybody than to work on human rights. 'People of different income levels cannot share the same discourse'. ${ }^{36} \mathrm{He}$ argued that China's discourse of a harmonious world was consistent with UNESCO's convention on the protection and promotion of the diversity of cultural expressions, meaning that different discourses should co-exist. An interview with an official from the Ministry of Foreign Affairs also showed that China was more confident with the government-to-government approach not because it was unaware of the necessity to reach out to the non-government sectors but because it did not have the experience of doing so at home. ${ }^{37}$ On the criticism of supporting African governments to suppress media freedom, the official from CRI argued:

Running a country is like running a household. The father may be very authoritarian. However, if the son has not succeeded in overthrowing the father that means the condition is not ready yet, whether we do business with the father or not. ${ }^{38}$

Interviews with academics showed that there was a close linkage between officials, academics and media professionals. This is also demonstrated by the frequent joint workshops hosted by media organisations, government officials, or academic institutions. Although interviewed scholars were critical of the government's way of doing things in Africa, they did not question what was done and could sometimes be defensive of what China was doing in Africa. On training journalists from Africa, one academic argued: 'When African journalists come to China, they are here only for about two weeks, unlike the US who trains them with a full package'. ${ }^{39}$ The training held at the Communication University of China, according to one academic, introduced not only Chinese-style journalism, but also western theories. Besides, he added, African journalists were only part of the students from developing countries: 'Why single them out?'. However, academics did think that Chinese media had a lot to improve before they could really have an influence in Africa. One complained that officials did not understand the alterations between domestic or international audiences, let alone the differences among international audiences: 'Leaders think that outside China there is only one other country'. ${ }^{40}$

Interviews with media professionals also yielded insights to the world in which they worked. They were well aware of the criticism coming from the West and were very defensive. For instance, on the issue of overwhelmingly positive reporting on Africa, one media researcher from Xinhua argued 'reporting on the negative side is not doing Arica any favours, as very few would then want to invest in the continent.' ${ }^{41}$ The female Xinghua journalist just back from four years' work in Africa cherished fond memories of

\footnotetext{
${ }^{35}$ Interview, 10 August, 2011.

${ }^{36}$ Interview, 12 August 2011.

${ }^{37}$ Interview, 30 July 2011.

${ }^{38}$ Interview, 2 August 2011.

${ }^{39}$ Interview, 11 May 2014.

${ }^{40}$ Interview with an African Studies academic, 28 July 2011.

${ }^{41}$ Interview, 29 July 2011.
} 
the continent, remembering the people as friendly and helpful. 'African people are proud people. They are keen not to see their country always reported negatively'. ${ }^{42}$ They believed that China was providing the world with a different perspective on Africa, while 'there are already enough reports in the world on the negative side'. ${ }^{43}$ On not providing in-depth reports, another media official from CCTV Africa argued 'this practice is in line with China's principle of non-interference'. ${ }^{44}$ On the credibility of state media, the answer from a media official was: 'Whoever reports does not matter. What matters is that what has been reported is true'. ${ }^{45}$

CCTV Africa has actively sourced local and international personnel. Interviews with local employees in CCTV Africa in Nairobi showed that the local employees, the majority of whom had worked in private media companies, brought with them different experiences to their new jobs. This ensures the expression of more subtle views on African and African related international issues.

\section{Balanced news reports in South Africa}

Zeleza sums up the various positive and negative portrayals of China in African media as fitting into one of three frames -- imperialism, globalization and solidarity. ${ }^{46}$ There is reason to suspect that reporting in South Africa's media might follow much the same pattern. Building on De Beer and Schreiner's 2009 study which pointed to the fact that news events pertaining to this relationship are likely to receive coverage, ${ }^{47}$ a content analysis was conducted of the data in the period of $2010-2012$ generated by the research company Media Tenor through a computerized content analysis of all mainstream 'traditional' platforms (excluding the web). ${ }^{48}$

\footnotetext{
42 Interview, 29 July 2011.

${ }^{43}$ Interview, 30 July 2011.

${ }^{44}$ Interview, 15 September 2012.

${ }^{45}$ Same interview as Footnote 37.

${ }^{46}$ Paul Zeleza, 'Dancing with the dragon: Africa's courtship with China', The Global South 2(2), (2008), p.174.

${ }^{47}$ A. S. De Beer and W.N. Schreiner, "Of "Ominous Dragons" and "Flying Geese": South African media coverage of China in Africa' (paper presented at the Annual Convention of the Association for Journalism and Mass Communication Education, Sheraton Boston, Boston, August 5, 2009).

${ }^{48}$ See Herman Wasserman, 'China in South Africa: the media's response to a developing relationship', Chinese Journal of Communication 5(3), (2012), pp.336-354; Herman Wasserman, 'South Africa and China as BRICS partners: Media perspectives on geopolitical shifts', Journal of Asian and African Studies, (December 16 2013), doi: 10.1177/0021909613514191for a more detailed discussion of these data.
} 


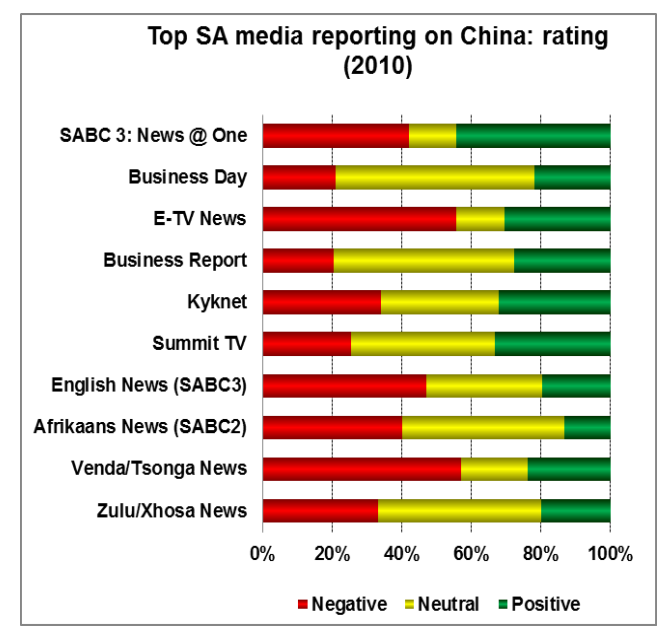

Figure 4. Tone of SA media reports on China:2010

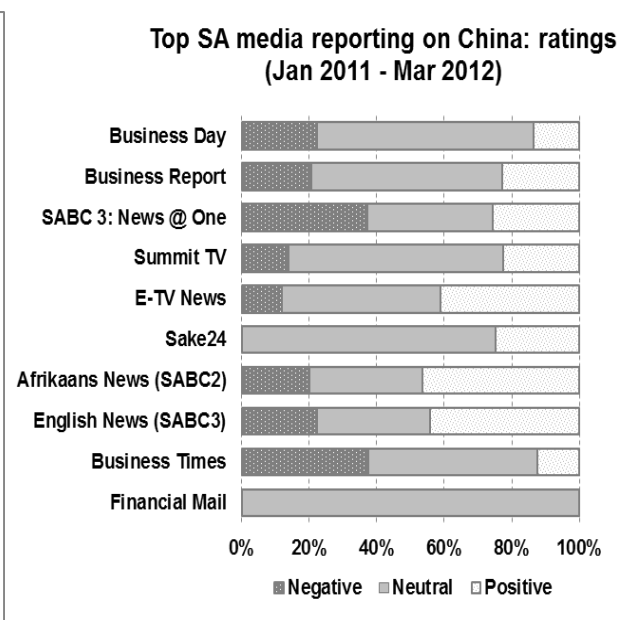

Figure 5. Tone of SA media reports on China: Jan. 2011 - March 2012

Figure 4 shows that the coverage of China in those outlets with the highest volume of reports was fairly balanced in 2010, with an almost equal balance in positive and negative statements on SABC 3 News, and a majority of neutral statements in Business Day. In 2011, even after the announcement of South Africa's accession to the BRIC group, both the top two outlets had a majority of neutral statements. A clear dip is however noticeble towards the middle of 2010, when reporting overall became quite negative before picking up again toward the end of 2010. An examination of the articles shows that this drop in positive reporting -- the only time during the two years under comparison here when reporting was consistently negative - was due to reporting on several natural disasters in China: the Yushu earthquake measuring 6.9 on the Richter Scale that struck in Qinghai, killing at least 2,000 and injuring more than 10,000; rainstorms in Southern China that left at least 115 dead in May; and flooding in June that killed at least 88 people and forced 750,000 to evacuate their homes.

As Figure 5 shows, the coverage from 2011 to 2012 continued to be dominated by 'neutral' reports. This could be a result of the nature of broadcast news bulletins as more general and superficial in their approach, highlighting only new events and developments which may come across as more positive in tone, than the more in-depth and critical analyses offered by the business media, which would weigh up different positions and therefore be coded as neutral. Business media are also likely to report more positively on stories that focused on China's economic investment in Africa, with less focus on the political or ideological implications.

A comparison with De Beer and Schreiner's 2009 study reveals a continuation of a balanced picture on China. This is unlike the assumptions in the literature about China as being portrayed either in highly positive terms as a saviour or close partner for African states, or in highly negative terms as an exploitative neo-colonial predator.

To understand and contexualize the findings from the content analysis, a purposive sample of editors and senior journalists was selected based on two criteria, namely their employment at one of the major media outlets analyzed in the content analyses and their seniority in the organization which is likely to amplify their influence over media content. After initial contact was established via email or telephone, an online questionnaire was 
administered to them in 2014. The 20 responses throw much light on the South African media professionals' perceptions of the Sino-Africa relations and China's influence on their work. It also offers insights to how the perception is translated into their daily work.

Responses to Question 1 on Sino-Africa relations yield no coherent perception. Those who show pessimism believe that the relationship is not equal, with China dictating the terms. The majority are not so sure, although 'fascinated' by what is happening. Question 2 , whether the close co-operation between the two countries will lead to good economic development in South Africa elicits not only varied answers but also reveal a great deal of concern. Apart from the five very confident 'yeses' and 'definitely' and a couple of negative views on the relationship, the majority of responses are uncertain, characterized by 'yes, however ...', 'yes, but ...', and 'yes and no'. One big worry is that the relationship may harm South Africa's relationship with the West.

Question 3 is designed to understand their views on the political implications of the relationship, and once again, the answers are mixed. Perceived benefits include 'moving away from the West', and 'potentially could form a counterweight against US/Europe in same political matters'. However, concerns far outnumber positive attitudes. Some respondents are concerned that a closer political tie would 'impact on South Africa's own internal politics or our government's democratic principles'. Strong words such as 'scary', 'recolonizations of Arica' and 'fear' are used because of 'China's draconian laws and lack of sympathy for opposing views' and 'more state intervention' leading respondents to feel that they 'would rather we kept our distance'. Some negative feelings derive from China not being transparent, 'so we never quite know who we are dealing with' and 'one has the fear of possible corruption'. However, one respondent warns that 'we cannot prejudge China's actions until we see what is on the table'.

The questions designed to find out about their consumption of Chinese media and their views on China's increased engagement in the African cultural and media sphere receive many negative responses. That Chinese media is controlled and censored is one of the main reasons leading them to the conclusion that so far they 'have little impact'; 'I can't see the African public consuming Chinese media'. Optimists, however, see a different picture because it will 'help Africans to better understand the lives of the Chinese and vice-versa'. One also welcomes it as 'a diversity of views is a positive development -why always just get the view from the West?'.

On China's investment in South Africa's media sector, apart from four clear negative attitudes, the majority are uncertain, typically starting the answer with 'Yes if', 'yes as long as', 'positive if' and 'positive development but ....' This shows again that many see it as a positive development, but they would like to see the control remains in South Africa's hands and media freedom safely guarded. One response summarizes all the rest: 'a strange mix of positive and negative censorship and control is always a worrying spectre, but new voices lend diversity to the landscape'.

When asked if closer contact with China and Chinese media will change the way they view their role, in spite of the differences with some very confident that it will not happen and some less certain, there is a shared hope that 'South African media won't change its role to adjust to China' as Chinese media is 'hardly a model you would want to emulate'.

Answers are predominantly negative when asked whether the South Africa media provide a fair representation of China and whether they have a role to play in creating a better understanding of China. One given reason is that few journalists have been to 
China and that most sources are from international media organisations. Some simply question where the resources would come from: 'Unrealistic to expect South African media to cover China. Who will pay for it?'; 'It is not the South African media's responsibility to create a better understanding of any specific country'; 'We've got far more important work to do than making China look better or presenting a better picture of it -- like telling our own stories better'.

The last question is to find out if respondents think Chinese media have been successful in creating a better image. With two exceptions, the majority give a negative answer. Few consume the Chinese media as they are considered inaccessible, unattractive or difficult to understand, and not relevant: 'And what does a Chinese TV channel and news agency mean to the man in a shack in Gugulethu? Probably not much'. Some prefer to believe that China has 'been successful in bringing African news to China more so than creating a better image of China'. For one respondent, 'Chinese soft power is much more influential in the gadgets it produces than in its news'.

\section{China's partial success in Zimbabwe's media sphere}

China's involvement in Zimbabwe has been long and historic, given how it supported the anti-colonial Chimurenga struggles in the 1970s. Today, high level visits and aid continue under the current coalition government. In contrast to the democratic South Africa, Zimbabwe falls into the category of 'problematic countries'. Widespread concerns have been noted on the growing official media relations, which have not only been hotly debated by Zimbabwean news media but also presented, defined or framed in ways meant to influence public opinion about China in Zimbabwe.

An analysis is conducted of a range of media from 2009 to 2012. The analysis shows that coverage of China has been increasing from year to year. Based on the Media Monitoring Project of Zimbabwe in The Herald databases, the following table points to the number of stories in which China was covered in different Zimbabwean media outlets from 2009 to 2012:

\begin{tabular}{|l|l|l|l|l|l|}
\hline & Medium & $\mathbf{2 0 0 9}$ & $\mathbf{2 0 1 0}$ & $\mathbf{2 0 1 1}$ & $\mathbf{2 0 1 2}$ \\
\hline 1 & $\begin{array}{l}\text { Zimbabwe Broadcasting } \\
\text { Corporation Television 1 } \\
\text { (ZBCTV) }\end{array}$ & 16 & 62 & 80 & 132 \\
\hline 2 & The Herald & 52 & 74 & 100 & 102 \\
\hline 3 & Sunday Mail & 7 & 16 & 4 & 15 \\
\hline 4 & NewsDay & 0 & 4 & 10 & 2 \\
\hline 5 & Standard & 3 & 8 & 7 & 11 \\
\hline 6 & The Daily News & 0 & 0 & 4 & 6 \\
\hline 7 & Radio Zimbabwe & 33 & 68 & 78 & 18 \\
\hline 8 & Spot FM & 18 & 25 & 26 & 4 \\
\hline 9 & Zimbabwe Independent & 5 & 11 & 3 & 19 \\
\hline
\end{tabular}

Table 1. Number of stories on China from 2009 to 2012 
As the figure below shows, government-controlled media -- the ZBC TV, The Herald, The Sunday Mail, Radio Zimbabwe and Spot FM -- allocated more space and time to the coverage of China. Privately-controlled media, namely Newsday, The Daily News, The Standard and the Zimbabwe Independent did not commit much space and time to covering China.

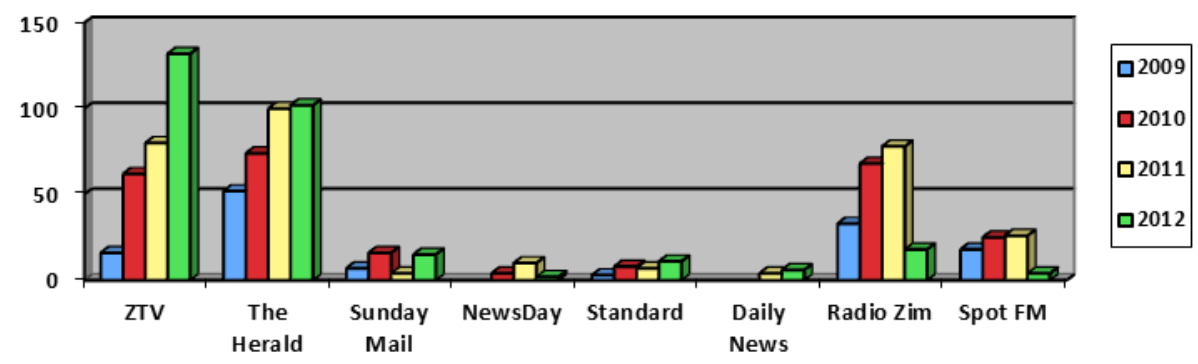

Figure 6. Space and time covering China from 2009 to 2012

The analysis also shows the different language used in describing China between public media and private media. The state-controlled media generally adopted a 'development journalism' style of reporting on China. Most of the stories were therefore positive, appreciating the Chinese as partners in development. China was described as 'Zimbabwe's all-weather friend' in some stories and the 'Asian economic giant' in others. A closer look at discourses in the stories pointed to an attempt to show that Beijing respected Zimbabwe's sovereignty and worked in the best interest of the country's development, supporting initiatives such as the land reform program, which western countries described as counter-productive. Where the West spoke of targeted measures against Zimbabwe's political elites, China was presented to refer to these as sanctions in resonation with the government's official position. China was also presented to be in support and recognition of Zimbabwe's liberation war politics as opposed to some western countries such as Britain and the USA that were portrayed as wanting to do away with the liberation war movement. China was also presented as anti-imperialist and the Look East Policy as an alternative to western-sponsored development initiatives. Stories also presented cultural cooperation through, for example, the introduction of Chinese language in schools. This counters the discourses of a neo-colonial modernity promoted by the West.

In sharp contrast, however, private media were critical of the relationship describing China as 'exploitative'. Some described the Chinese as people who were long on trade but short on investment while others described China as 'a dominant force in the resource rush' or as slave drivers and cruel employers who demand excessive work from workforces without bothering to improve their working conditions and remunerations.

Overall, the state-controlled media showed enthusiasm for the continued friendly relation with China while the language in private media -- akin to liberal discourses called for an open, unrestrained free market system. While China was acknowledged as a fast growing economy, its model was portrayed to be having a missing link in terms of promoting civil liberties. The examination also showed that most stories in the private media took a slant from western news agencies such as Reuters, Associated Press, AFP 
and others that purveyed liberal discourses. Thus, the Chinese model of business was portrayed as feudalistic and exploitative.

In-depth interviews carried out in 2013 and 2014 yield insights to the varying extent of China's influence on different media sectors. For instance, the Union of Journalists has had close relationship with China since 2000. It frequently sends journalists to go to China on the exchange program. However, an interview with the Information Officer of the Union showed that while he was very positive on some aspects he was equally critical on others, which could be summarized in his own words: 'There are pros and cons of China coming to Zimbabwe'. ${ }^{49}$ To be specific, he thought highly of the employment opportunities China brought to the country, and yet he was very uncomfortable with China's 'government-to-government approach' because China 'does not deal with the civil society and therefore uses our relationship with media employers'. He was also critical of the 'check-book diplomacy', and wary of the dependency syndrome that he believed China was promoting. In addition, 'China promotes a culture of consensus, centralization and "a one-party model", while helping the Zimbabwe government jam "dissident radio stations". The paid trips to China, in his view, were self-serving because 'they are a way of whipping Zimbabwean journalists into line' and as a result 'ideology is present in media content, even in cooking programmes on television. The trips are resulting in partisan coverage'. He revealed that:

Friendly journalists are handed trips easily and all journalists are carefully vetted... You cannot propose a journalist who is too critical of the Chinese. Some names are turned down. With the Herald they wish they can take the entire team.

He added, ' $\mathrm{ZBC}$ is increasingly broadcasting boring Chinese programmes. CCTV has a slot on ZBC. In our news sources China is becoming more and more visible'.

Mr. X, a trade journalist at the Zimbabwe Congress of Trade Unions (ZCTU) since 1996, was very open in his criticism of the relationship. To him, China came to Africa 'to satisfy its need for resources'. ${ }^{50}$ He believed that the relationship was asymmetric, with China literary 'taking over all sectors' and 'cutting deals that have destroyed our industries'. In addition, he believed that China 'supports public media already friendly to them'.

In sharp contrast, a Deputy Minister spoke highly of the journalism exchange programs:

When journalists go to China they come back with a totally different perspective about China. They can see what the Chinese are doing or have done and they start to appreciate that in terms of development... There is nothing lucrative about the Chinese trip. It is very mischievous to suggest that there is more reportage because they are getting incentives.

The anti-China view, to him, was a sponsored position driven by western interests:

I think a lot of the media and Zimbabwe people have been believing Western narratives about China that they are here to loot the resources and their country is not a democracy;

\footnotetext{
${ }^{49}$ Interview in Harare, 11 April 2013.

${ }^{50}$ Interview in Harare, 12 April 2014.
} 
its Third World and still developing. ... It is a view planted by those with an agenda to perpetuate western narratives about China and link with the country with corruption.

What is important to him is that 'we work on cultural exchanges. If we watch CCTV then they should also watch ZBC in China'.

China has been purchasing equipment annually for state broadcaster/state publications and was greatly involved with the setting up of Star FM. Therefore the interview with the General Manager of ZBC only confirmed the good relationship China enjoyed with it: 'Broadly speaking we have seen benefits for Zimbabwe... ZBC is a good example'. ${ }^{51}$ In addition to the buses from China for civil servants ZBC regularly sends technical people for training in China.

We acquired an Outside Broadcasting van from China, a first for this country, for Southern Africa if not for Africa. It helps us broadcast anything from anywhere to anywhere in the world. We have an agreement with Xinhua. We share news and equipment. We share resources. We now have an up link and they can broadcast from here.

Another benefit from having close cooperation with China is that 'China has helped put pressure on the West so that they can reengage. It has helped because now the West says let's sit down and talk'. However, although 'technically China can provide what the West provides', he admits that 'in terms of content we have not done well. Obviously their businesses need to be qualitatively good'. On China's influence on their role he argues that ' $\mathrm{ZBC}$ has been able to criticize China when necessary.... We are good friends but we have been able to say our friends are not doing well'. Yet he agrees:

I think it has this psychological impact on you, sometimes it's difficult... We hear stories of problems with labor but such stories have not come out because the media think these people are helping us.

Finally a group interview was also conducted with eight university students, while their views on China's presence in Zimbabwe were mixed, ${ }^{52}$ they were well aware of the differences in the coverage of China between the state and the independent media. They were critical of the government media who had been too supportive. They also thought of Chinese programs on ZTV 'boring' and therefore they did not watch them.

\section{Conclusion: challenges and prospects}

This paper has examined the different moments of China's soft power efforts in Africa -projection, representations and reception - for an understanding of how successful China is in spreading its influence in Zimbabwe and South Africa. Our study has demonstrated that China's state-led soft power initiatives in Africa have achieved some desired results. Its advantages in easy deployment of resources are obvious - the official 'Big Four' have all greatly increased their presence in Africa, which caused former U.S. Secretary of State Hillary Clinton to suggest at a Congressional Committee Hearing in 2011 that if there is

\footnotetext{
${ }^{51}$ Interview in Harare, 17 April 2013.

52 Interview in Harare, 16 April 2013.
} 
an 'information war' between China and the United States on an African battleground, it appears that China is beginning to win the war. ${ }^{53}$

Analysis of China's major official media discourses and interviews with Chinese officials show that China wants its engagement in Africa to be seen as mutually beneficial rather than asymmetric. It wants to increase its influence and build a good image in Africa as much as in other parts of the world. It aligns with African countries for not only economic reasons but also for Africa's support for its domestic and foreign agendas. It also constructs a discourse that not only poses an alternative to the western one but also a challenge to the existing US-led world order. Interviews with officials show that China does not intend to become a rival for resources in Africa. The academics and media professionals interviewed are supportive of China's increase of influence in Africa. They endorse the practice of providing a different perspective on Africa, so that rather than contributing to the stereotyping of African countries as poverty-stricken and war-torn, China offers more positive reporting on Africa.

Content analysis of major Zimbabwe media demonstrates that China's state-centred model and the 'government-to-government' approach has achieved some impressive results in Zimbabwe, as is demonstrated by the public media coverage of ChinaZimbabwe relations and interviews with government officials and public media organisations. Through different approaches China is not only enjoying a much bigger presence in the Zimbabwe public media, but also a much more favorable image. The emerging overall balanced view in three consecutive years in the range of South Africa's media reports once again lead one to conclude that the media has an influence on public opinions as it corresponds with Pew Research Centre's findings in 2014 that South Africans are 'closely divided (45\% favorable, $40 \%$ unfavorable)'. ${ }^{54}$ It also suggests journalists' and editors' understanding that China's role in South Africa is a complex one which cannot be pigeonholed as either a 'bad' or 'good' news story.

However, analysis of private media in Zimbabwe and interviews conducted in China, South Africa and Zimbabwe also reveal that China has so far achieved partial success only. It is not surprising that the public, under the influence of both international and domestic media, public and private, are divided in their views about China in the two countries. Online responses also indicate that China is far from being able to assuage independent-minded editors and journalists in South Africa. It is predictable from responses from media professionals in South Africa that resistance will be strong if there is any pressure from the Chinese investors to try to shape the media sphere. Our study therefore points to the challenges China faces in fully convincing African publics that its engagement is positive.

Joseph Nye in 2006 rightly stated: '[W] hether power resources produce a favorable outcome depends upon the context'. ${ }^{55}$ China's non-democratic political system is the main cause of suspicion and even fear among South African editors and journalists as well as the private Zimbabwean sectors. This concern leads most South Africa respondents, while believing in the economic benefits and welcoming China as an

\footnotetext{
${ }^{53}$ York, 'Why China is making a big play to control Africa's media'.

54 'Global Opposition to U.S. Surveillance and Drones, But Limited Harm to America's Image', last modified 14 July, 2014, available at: http://www.pewglobal.org/2014/07/14/chapter-2-chinas-image/ (accessed 4 October 2015).

${ }^{55}$ Nye, 'Think again: soft power'.
} 
alternative to the West, to advocating caution in dealing with China. One response in South Africa reveals why caution is needed: 'it may not be good for South Africa's image to be seen as having too strong ties with the Communist Party of China (CPC)'.

Related to the above is the credibility issue of the Chinese official media working within the one-party political system. On the one hand they need to work out how to reconcile their role as loyal CPC mouthpieces and as trusted news sources. On the other the absence of alternative and independent media inside China itself makes it impossible for Chinese policymakers to draw on the expertise of the kind of media that attract international audiences' attention. The lack of officials' understanding of the different contexts within which soft power works explains to some extent why the state-controlled media are not appealing to most African media public.

In addition, China's 'government-to-government' approach proves to have largely failed to win media professionals' hearts in the democratic South Africa or in the private media organisations in Zimbabwe. Since the Cold War, public diplomacy is taking place in an international environment which can no longer be described as exclusively statecentered. This new public diplomacy extends beyond the operations of government altogether to the activities of the private sector and of wider society and culture. Interviews with Chinese officials show an increasing understanding of the need to reach out to civil society. However, doing so is going out of China's comfort zone because of a lack of experience at home.

Finally, Chinese state media organizations continue to face difficulties in competing with international media organizations such as the $\mathrm{BBC}$ or $\mathrm{CNN}$ in Africa. Interviews indicate that western media's influence on the media public as well as media organisations is still strong. This is partly due to historical reasons, but also the 'quality' of the Chinese media that is not up to the standard of other international media organisations.

Investigation needs to be done as to whether it is only wishful thinking from the interviewed deputy Zimbabwe minister when he stated that 'we work on cultural exchange. If we watch CCTV here then they should also watch ZBC in China'. But the message is clear: the relationship should be reciprocal if it is to be sustainable. What also deserves attention is that while China is keen to align with African countries to challenge the West-dominated global order, both responses to the questionnaire and interviews in Zimbabwe show that African countries are also using China's attention to get the West to reengage with the continent.

China will be taking on a larger role in Africa, as Xi told African leaders. ${ }^{56}$ Wenping He of the Think Tank on Africa from the Chinese Academy of Social Science has also advocated 'more soft power in Africa' ${ }^{57}$ China therefore needs to make a more profound reconsideration of its overall strategic engagement with Africa to resolve the aforementioned problems in further expanding its influence in Africa. However, given the difficulties of changing the nature of the media under the current political system these issues will most likely remain unchanged in the near future.

\footnotetext{
56 'China set to expand influence in Africa on back of Xi Jinping's trip'.

${ }^{57} \mathrm{He}$, 'More soft power needed in Africa'
} 